\title{
Iliac artery myointimal hyperplasia in rabbits submitted to angioplasty and treated with Moringa oleifera
}

\section{Hiperplasia miointimal na artéria ilíaca em coelhos submetidos à angioplastia e tratados com Moringa oleifera}

Jânio Cipriano Rolim"; Manoel Ricardo Sena Nogueira ${ }^{1}$; Paulo Roberto da Silva Lima ${ }^{2}$; Francisco Chavier Vieira Bandeira ${ }^{2}$; Mizael

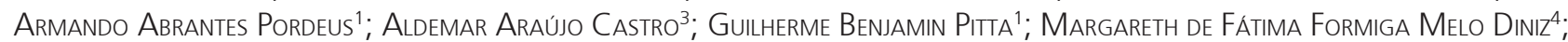
Adamastor Humberto Pereira, TCBC-RS 1

\section{A}

\begin{abstract}
Objective: to assess post-angioplasty myointimal hyperplasia in iliac artery of rabbits treated with extract of Moringa oleifera leaves. Methods: we conducted a randomized trial in laboratory animals for five weeks of follow-up, developed in the Vivarium of Pharmaceutical Technology Laboratory of the Universidade Federal da Paraíba. We used rabbits from the New Zealand breed, subjected to a hypercholesterolemic diet and angioplasty of the external iliac artery, randomized into two groups: M200 Group $(n=10)$ - rabbits treated with $200 \mathrm{mg} / \mathrm{kg} /$ day of Moringa oleifera leaves extract orally; SF group $(n=10)-$ rabbits treated with $0.9 \%$ saline orally. After five weeks, the animals were euthanized and the iliac arteries prepared for histology. Histological sections were analyzed by digital morphometry. Statistical analysis was performed using the Student's t test. The significance level was 0.05 . Results: there was no significant difference in myointimal hyperplasia between M200 and SF groups when comparing the iliac arteries submitted to angioplasty. Conclusion: there was no difference of myointimal hyperplasia between groups treated with saline and Moringa oleifera after angioplasty.
\end{abstract}

Key words: Hyperplasia. Ilíac Artery. Moringa oleifera. Angioplasty. Rabbits.

\section{INTRODUCTION}

In its history, Reconstructive Vascular Surgery has faced a complex biological phenomenon affecting results, which is the anastomosis myointimal hyperplasia and the fibroplasia, developed in vascular anastomosis or after balloon angioplasty, often leading to vascular occlusion and failed revascularization. Over the years, several researches have been dedicated to the study of the intima and the control of such phenomenon by pharmacotherapeutic agents, but the results are still far from satisfactory'.

Myointimal hyperplasia is the proliferation and migration of smooth muscle cells of the arterial medial layer and bone marrow cells to the intimal layer, thus decreasing the vascular lumen².

Moringa oleifera (M. oleifera), also known as Moringa pterygosperma Gaertn, is a member of the plant family Moringaceae, perennial angiosperms, including 12 other species. Native of sub-Himalayan northern parts of India, it is cultivated in all tropical and subtropical areas of the world, where it is known by several common names: drumstick tree, horseradish tree and malunggay, this most commonly found in the literature ${ }^{3}$.

Moringa oleifera is an edible plant. A wide variety of nutritional and medicinal properties have been attributed to its roots, bark, leaves, flowers, fruits and seeds ${ }^{4,5}$. Phytochemical analyses have shown that the leaves are particularly rich in potassium, calcium, phorous iron phosphate, vitamins $A$ and $D$, essential amino acids, and known antioxidants such as â-carotene, vitamin $C$ and flavonoids ${ }^{6-10}$.

Moringa's flower has high medicinal value as a stimulant, aphrodisiac, abortifacient and anti-inflammatory. It acts in muscle diseases, has antitumor action, decreases triglycerides, as well as serum cholesterols and its fractions - Very Low Density Lipoprotein (VLDL), Low Density Lipoprotein ( $L D L)$, improving the atherogenic index. It decreases lipid profile in the heart, liver and aorta of hypercholesterolemic rabbits and increases fecal excretion of cholesterol. The leaves have purgative activities, applied as a poultice for wounds. It has been used in temples for headaches, as well for hemorrhoids, fever, sore throat,

1. Universidade Federal do Rio Grande do Sul - UFRGS, Porto Alegre, RS, Brasil; 2. Universidade Federal de Alagoas - UFAL, Maceió, AL, Brasil; 3. Universidade Estadual de Ciências da Saúde de Alagoas - UNICISAL, Maceió, AL, Brasil; 4. Universidade Federal da Paraíba - UFPB, João Pessoa, PB, Brasil. 
bronchitis, eye and ear infections, scurvy and phlegm. It is believed that the leaf juice is effective for controlling glucose levels ${ }^{4}$.

Experimental data ${ }^{11}$ and the first clinical trials have shown that inhibition of myointimal hyperplasia can be achieved by local administration of antiproliferative drugs such as paclitaxel loaded on the surface of angioplasty balloons. Therefore, drug-eluting balloons are a promising tool to prevent restenosis and unwanted persistence of the polymers of drug-eluting stents in the vessel wall, thereby, potentially increasing the safety of the percutaneous coronary intervention ${ }^{12-14}$

This research aimed to determine the difference in frequency of post-angioplasty myointimal hyperplasia in the iliac artery of rabbits with experimental atherosclerosis treated with extract from the leaves of Moringa oleifera.

\section{METHODS}

The project was approved by the Ethics Committee on Animal Research of the Pharmacological Technology Laboratory (CEPA / LTF) of the Universidade Federal da Paraíba (UFPB), Campus I, Joao Pessoa, PB (protocol 602/2011), and the research developed in the Vivarium of the Laboratory of Pharmaceutical Technology.

\section{Study Type}

Randomized clinical trial in experimental animals for five weeks follow-up.

\section{Sample}

\section{Inclusion criteria}

We included 20 young, adult, female rabbits (12 months of age and weighing over $2 \mathrm{~kg}$ ) from Oryctolagus cuniculus species and New Zealand strain, undergoing an intimal hyperplasia process of the left common iliac artery after experimental atherosclerosis by egg yolk ${ }^{15}$.

\section{Exclusion criteria}

We excluded rabbits older than six months, body weight less than $2 \mathrm{~kg}$ and more than $4 \mathrm{~kg}$, with preexisting disease or anatomical changes in studied structures.

\section{Sampling}

We studied the selected rabbits, which formed a probabilistic sample.

\section{Randomization}

The draw of the animals for each group was made randomly by block permutation ${ }^{16}$ with the aid of the Research Randomizer software (available at: http:// www.randomizer.org/form.htm), two blocks with ten numbers. Each block corresponded to a group, and the numbers generated, to animals. They formed two groups with ten rabbits each.
Animals received a letter corresponding to the group and a number (example: M1 - Moringa group, Animal 1; C2 - Control group, animal 2). This marking was performed by writing made by blue indelible ink (permanent mark) on the internal aspect of the base of the ear.

Atherosclerosis was induced by a hypercholesterolemic egg yolk-based diet, $20 \mathrm{ml} /$ day divided into two oral doses for a period of 100 days.

We opted for closed animal management and the experiment was carried out on the same vivarium of origin, where there is an enabling environment for them, with forced ventilation, exhaust system, periods of natural luminescence, average temperature of $20^{\circ} \mathrm{C}$, minimum noise and moisture around $50 \%$. We kept the animals in individual cages with appropriate area $0.64 \mathrm{~m}^{2}$, without contact with the natural secretions, since they are adapted in order to maintain proper hygiene. The diet consisted of water and granulated commercial chow ad libtum before and during the experiment, according to the literature ${ }^{17}$.

We induced the myointimal hyperplasia by the following technique: The rabbits were anesthetized with xylazine at a dose of $10 \mathrm{mg} / \mathrm{kg}$ and ketamine at a dose of $40 \mathrm{mg} / \mathrm{kg}$ intramuscularly in the thigh. Oxygenation was maintained by endotracheal intubation by direct visualization, coupled to the source of $\mathrm{O}_{2}$ with the aid of anesthesia ${ }^{18}$. After anesthetic induction, we carried out trichotomy of the lower abdomen and groin followed by adequate local cleaning and antisepsis with iodized alcohol. The procedure was then the skin incision of 2 to $3 \mathrm{~cm}$ in length in the longitudinal direction in the inguinal fold with a 15 scalpel blade, for exposing the right femoral artery, which was repaired with simple interrupted sutures of nylon 3.0 at the end of the procedure. A blood sample was collected for Total Cholesterol, High Density Lipoprotein $(\mathrm{HDL}), \mathrm{LDL}, \mathrm{VLDL}$ and triglycerides. This blood was sent to the vivarium biochemistry laboratory for the respective dosage. We than performed a small cross arteriotomy with a 11 scalpel blade, by means of which we introduced a metal guide number 0.014 , over which we introduced the balloon catheter of $3 \mathrm{~mm}$ diameter by $20 \mathrm{~mm}$ length (balloon/artery ratio of 2.5-3.0: 1) which was inserted into the lumen of the right iliac artery (RIA). In each artery, the balloon catheter was inflated for a minute at rated pressure, leading to distension of the arterial wall. After deflation of the balloon we performed ligation of the arteries with 3.0 cotton sutures. Finally, the skin was sutured with 3.0 nylon sutures. We administered analgesics (Ibuprofen $10 \mathrm{mg} / \mathrm{kg}$ orally for five days) and antibiotics (cefaclor $20 \mathrm{mg} / \mathrm{kg} /$ day divided into two doses) for both groups postoperatively to prevent animal suffering. Twenty-four hours after the arterial injury, we began the administration of our research drugs in both groups.

Group M (Moringa) received $200 \mathrm{mg} / \mathrm{kg}$ of ethanol extract of Moringa oleifera leaves by gavage for 
five weeks and group C (negative control) received 0.9\% saline, $10 \mathrm{ml} /$ day for five weeks by gavage.

By the end of the experiment, the animals were euthanized by a lethal dose of the anesthetic, and we harvested the common iliac arteries with the segment subjected to the lesion by the balloon. In addition, we collected new blood samples to measure total cholesterol, $\mathrm{HDL}, \mathrm{LDL}, \mathrm{VLDL}$ and triglycerides. Arterial specimens were fixed in 10\% formalin for at least 24 hours and then brought to the routine preparation of histological sections for light microscopy: gradual and increasing dehydration in $70 \%$ alcohol to absolute alcohol - diaphanization in xylene and embedding in liquid paraffin at $60^{\circ} \mathrm{C}$. Paraffin blocks thus prepared were cut with a microtome at a thickness of 3ìm and cuts mounted on extra-thin glass slides $(76 \times 25 \mathrm{~mm})$. They were stained with hematoxylin-eosin (HE), then mounted with coverslips and natural resin. The slides were prepared and examined by a pathologist duly accredited with increases of 10 and 40 times.

The blood was sent to the laboratory, where we held the standard dosage of the above parameters.

Pathologist blinding was performed by sequential numbering, the true correlation being known only by the one who had marked the ears (Principal Investigator). The new identitification was kept in a sealed envelope, which was not opened untill the time of data analysis, after the measurement of the primary variable.

After histological analysis, the slides were photographed with a digital camera (Canon PowerShot $A 640 \AA)$ in $4 x$ optical magnification associated with the optical microscope (Nykon $\AA$ ) increases of $2 x$ and 10x.

The images of histological sections stained by HE were scanned for morphometric analysis from the conventional optical microscope with objective $2 x$ with planachromatic lenses, colored closed circuit camera with $4 x$ optical zoom, generating image files of 3,648 $\times 2,736$ pixels. The images were scanned using $2 x$ microscopic enhancement. The morphometric measurements were performed by the processing and digital analysis system "ImageJ64 NIH Image", without the interference of the observer, kept "blind" during the measurement. For each segment analyzed we measured the lumen area and the inner area of the internal and external elastic lamina. Based on these results, we calculated: 1) the area of the medium- intimal layer - subtracting the vessel wall region between the external elastic lamina and the lumen of the vessel; 2) the index of medium-intimal hyperplasia - dividing the average area of intimal layer by its sum with the lumen of the vessel.

The primary variable was the frequency difference of average myointimal hyperplasia.

For effective treatment, the myointimal hyperplasia was assessed by morphometry; values were in area and pixels, then we calculated the mean of each group. The difference of these mean area was the one used to tell which treatment was more efficient.
Secondary variables were total cholesterol and its fractions (HDL, LDL, VLDL) and triglycerides.

As additional data, we studied the animals body weight. The kilogram is the amount of mass, it is equal to the mass of the international kilogram prototype ${ }^{19}$; age (calculated in full months, on the last day of the reference month of the research, based on the day, month and year of the animal's birth).

\section{Statistical Method}

Calculating the sample size

The sample size was arbitrated in 20 rabbits, based on the literature, where there are works that demonstrate acceptable statistical results with fewer animals in the experiment with similar animal models ${ }^{20-22}$, and to respect the rules of the Brazilian Society of Science in Animal laboratories (SBCAL). Statistical analysis was performed with the Student's t test and calculating the 95\% confidence interval (Cl) for each point estimate.

Statistical analysis

We collected data in a standardized form and stored them in a spreadsheet. We performed descriptive analysis by calculating the $95 \%$ confidence interval for each estimated point. The calculations were performed with the aid of statistical GraphPad Instat $®$ Prism 5 (2012), Mac version.

Data are presented as mean and standard deviation. The comparison between groups was performed using the Mann-Whitney $U$ test for morphometric data. The calculations were performed with the aid of statistical GraphPad Prism Instat@ 5 (2012), Mac version.

\section{RESULTS}

When comparing the average of the mediumintimal complex of groups (SF $=35.74 \%$ of the artery versus $\mathrm{M} 200=38.66 \%$ of the artery), there was no statistical difference when we applied the Mann-Whitney $U$ test $(p=0.33$-Table 1).

When comparing the values of total cholesterol, $\mathrm{HDL}$, LDL and triglycerides, there was no statistically significant difference.

As for weight, there was difference in the means of both groups when comparing the periods before and after the experiment (Tables 2-5 and Figure 1).

\section{DISCUSSION}

The study was performed in rabbits, as Yanni showed that New Zealand rabbits (Oryctolagus cuniculus) are very sensitive to induction of atherosclerotic lesions and considers this strain as one of the most important atherosclerosis study model ${ }^{20}$. The construction of models inducing atherosclerosis, pharmacologically or by 
Table 1 - Medium-Intimal Complex of the iliac arteries.

\begin{tabular}{lcccrr}
\hline Group & Mean (\%) & Standard Deviation (+/-) & $95 \%$ Cl & Min & Max \\
\hline SF 0.9\% & 35.74 & 5.56 & 31.76 a 39.71 & 29.23 & 45.46 \\
M 200 & 38.66 & 7.39 & 33.37 a 43.94 & 24.1 & 47.02 \\
\hline
\end{tabular}

$P=0.33$

atherogenic diet, associated with angioplasty balloon injury, results in formation of plaques similar to those found in human coronary arteries ${ }^{20}$.

Brasselet et al. also used iliac arteries of rabbits subjected to experimental atherosclerosis diet with high cholesterol content ${ }^{21}$. However, the analysis of the iliac arteries of rabbits countered the prevalence of atherosclerotic lesions, which are more often in the aortic arch and thoracic aorta of rabbits submitted to experimental atherosclerosis, according to Taylor and Fan ${ }^{22}$.

The iliac area was chosen for the availability of data showing that this site is a territory in which angioplasty may be performed, including selective implantation of stents ${ }^{23}$, which was not done in this study since we opted only by angioplasty balloon. The classic study from Indolfi et al., who used a Fogarty catheter to cause endothelial injury, showed that restenosis after balloon catheter angioplasty was caused by the negative elastic remodeling and the proliferation and migration of vascular smooth muscle cells (VSMC) ${ }^{24}$. In said model, using carotid arteries of rats, the response of the arterial wall damage caused by angioplasty is the release of growth factors and other biologically active factors, which changing the composition of the extracellular matrix and

Table 2 - Premedication lipid profile - SF Group.

\begin{tabular}{|c|c|c|c|c|c|}
\hline & & $0.9 \%$ Saline & & & \\
\hline & Mean & Standard Deviation (+/-) & $95 \% \mathrm{Cl}$ & Max & Min \\
\hline Cholesterol Total (mg/dl) & 53.1 & 50.11 & $17.26-88.94$ & 194 & 25 \\
\hline $\mathrm{HDL}(\mathrm{mg} / \mathrm{dl})$ & 20.87 & 6.966 & $15.887-25.853$ & 32.8 & 3.9 \\
\hline $\mathrm{LDL}(\mathrm{mg} / \mathrm{dl})$ & 14.8 & 37.37 & $11.93-41.53$ & 120 & -6 \\
\hline $\operatorname{VLDL}(\mathrm{mg} / \mathrm{dl})$ & 17.5 & 18.65 & $4.16-30.54$ & 70 & 9 \\
\hline Triglycerides (mg/dl) & 88.5 & 95.44 & $20.22-156.78$ & 269 & 39 \\
\hline
\end{tabular}

Table 3 - Post-medication lipid profile - SF Group.

\begin{tabular}{|c|c|c|c|c|c|}
\hline \multicolumn{6}{|c|}{$0.9 \%$ Saline } \\
\hline & Mean & Standard Deviation (+/-) & $95 \% \mathrm{Cl}$ & Max & Min \\
\hline Cholesterol Total (mg/dl) & 46.4 & 19.66 & $32.33-60.47$ & 97 & 31 \\
\hline $\mathrm{HDL}(\mathrm{mg} / \mathrm{dl})$ & 19.08 & 16.189 & $7.499-30.661$ & 53.8 & 7.8 \\
\hline LDL (mg/dl) & 11.17 & 9.815 & $4.149-18.191$ & 38 & 4.7 \\
\hline $\operatorname{VLDL}(\mathrm{mg} / \mathrm{dl})$ & 16.15 & 6.627 & $11.409-20.891$ & 26.7 & 5.2 \\
\hline Triglycerides (mg/dl) & 95.4 & 80.95 & $37.49-153.31$ & 269 & 39 \\
\hline
\end{tabular}

Table 4 - $\quad$ Premedication lipid profile - M 200 Group.

\begin{tabular}{|c|c|c|c|c|c|}
\hline & \multicolumn{5}{|c|}{ M 200} \\
\hline & Mean & Standard Deviation (+/-) & $95 \% \mathrm{Cl}$ & Max & Min \\
\hline Cholesterol Total (mg/dl) & 44.75 & 11.23 & $35.36-54.14$ & 61 & 29 \\
\hline $\mathrm{HDL}(\mathrm{mg} / \mathrm{dl})$ & 23.513 & 3.702 & $20.418-26.607$ & 55 & 28 \\
\hline LDL (mg/dl) & 5.13 & 12.02 & $4.92-15.17$ & 25 & -9 \\
\hline $\operatorname{VLDL}(\mathrm{mg} / \mathrm{dl})$ & 16.25 & 3.58 & $13.26-19.24$ & 20 & 10 \\
\hline Triglycerides (mg/dl) & 82.63 & 18.41 & $67.24-98.01$ & 100 & 51 \\
\hline
\end{tabular}


Table 5 - $\quad$ Post-medication lipid profile - M 200 Group.

\begin{tabular}{|c|c|c|c|c|c|}
\hline & \multicolumn{5}{|c|}{ M 200} \\
\hline & Mean & Standard Deviation (+/-) & $95 \% \mathrm{Cl}$ & Max & Min \\
\hline Cholesterol Total (mg/dl) & 42.56 & 11.2 & $33.94-51.17$ & 55 & 28 \\
\hline $\mathrm{HDL}(\mathrm{mg} / \mathrm{dl})$ & 22.778 & 9.101 & $15.782-29.773$ & 37.5 & 5.1 \\
\hline LDL (mg/dl) & 3.889 & 8.525 & $2.664-10.442$ & 22.7 & -5.2 \\
\hline $\operatorname{VLDL}(\mathrm{mg} / \mathrm{dl})$ & 15.9 & 6.13 & $11.188-20.612$ & 27.2 & 9.4 \\
\hline Triglycerides (mg/dl) & 79.44 & 30.66 & $55.87-103.01$ & 136 & 47 \\
\hline
\end{tabular}

promote phenotypic change in VSMC, from the contractile to synthetic (dedifferentiation), leading to cell proliferation in the tunica media and migration into the intima, forming the neointima ${ }^{24}$. Likewise, Inouye et al. used balloon angioplasty to simulate, with greater reliability, the stress induced by angioplasty ${ }^{25}$. This research was carried out by inflating a $3.0 \times 20 \mathrm{~mm}$ angioplasty balloon in the iliac artery of rabbits using the maximum balloon rated pressure (burst pressure) for a period of one minute and following a balloon:artery ratio of 2.5 3.0: 1, while in the study by Taylor ${ }^{22}$ this ratio was 1.0-1.2: 1 .

The survey results showed no significant effect in reducing weight, cholesterol or triglycerides, the secondary variables, unlike the work of Metha et al., which showed a hypolipidemic effect and influence in the decrease in the rabbits' weight ${ }^{26}$. This research, as well as the one from Mehta et al., used the dosage of 200mg/ $\mathrm{kg} /$ day of an alcoholic extract of leaves, and that author used the fruits during the period of 120 days. In our study, the intervention was made in 35 days, as the main objective was to evaluate the effect of Moringa leaf extract in intimal hyperplasia, since the phases of intimal hyperplasia revolve around four weeks, according to the literature and to Indolfi et al. ${ }^{24}$.

Karas et al. defend the pig model as an ideal one for reproduction of hyperplasia ${ }^{27}$. However, a good restenosis model requires more affordable, accessible and easy to handle animals. As Le Tourneau et al. ${ }^{28}$, we chose to use the iliac arteries of hypercholesterolemic rabbits as the animal model for atherosclerosis and myointimal hyperplasia.

Jain et al. used up to $600 \mathrm{mg} / \mathrm{kg} /$ day when evaluating hypolipidemic activity of the Moringa oleifera $L_{a m}{ }^{29}$. Thus, other higher concentrations may be tested.

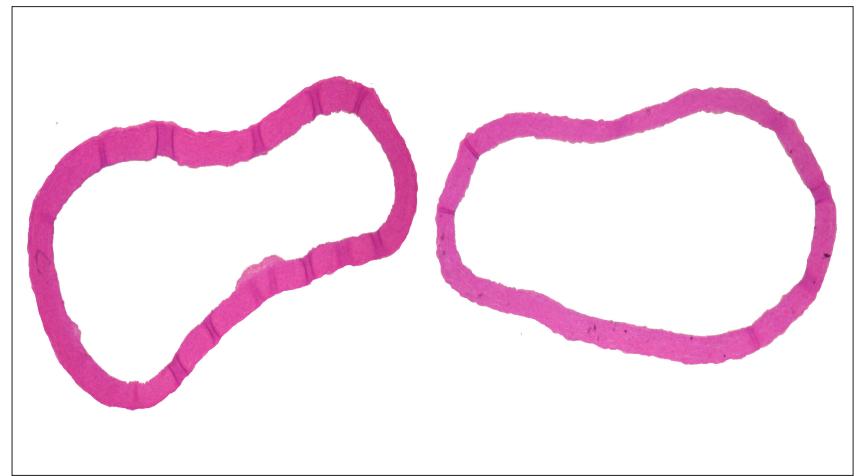

Figure 1 - Rabbits' arteries medium-intimal complex photomicrograph. Left - Moringa oleifera Group $200 \mathrm{mg} / \mathrm{kg} /$ day. Right - Control Group; $8 x$ magnification, $H E$.

Regarding lipid levels, was did not observe statistical difference either, perhaps because the atherogenic diet has been suspended in the period following angioplasty.

Finally, the investigation showed no significant difference from the myointimal area when comparing the control group, which used saline, with the group that was treated with the Moringa leaf extract at a dose of 200mg/ $\mathrm{kg} /$ day, this dosage of Moringa extract possibly being too low.

Studies with higher doses of Moringa leaf extract should be performed, and with the testing of other parts of the plant, since there is a growing number of studies showing beneficial effects when it is used for medicinal purposes.

In conclusion, there was no difference in the frequency of myointimal hyperplasia between iliac arteries of rabbits treated with saline and with Moringa oleifera after angioplasty at the tested concentration. 


\title{
R E S U M O
}

\begin{abstract}
Objetivo: determinar a diferença da média de hiperplasia miointimal pós-angioplastia na artéria ilíaca de coelhos tratados e não tratados com extrato das folhas de Moringa oleifera. Métodos: ensaio aleatório em animais de laboratório por cinco semanas de seguimento, desenvolvido no Biotério do Laboratório de Tecnologia Farmacêutica da Universidade Federal da Paraíba. Foram utilizadas coelhas da raça Nova Zelândia, submetidas à dieta hipercolesterolêmica e angioplastia da artéria ilíaca externa, randomizadas em dois grupos: Grupo M200 ( $n=10)$, coelhas tratadas com 200mg/kg/dia de extrato de folhas de Moringa oleifera, por via oral; Grupo SF $(n=10)$, coelhas tratadas com soro fisiológico $0,9 \%$, por via oral. Após cinco semanas, os animais foram eutanaziados e as artérias ilíacas preparadas para histologia. Os cortes histológicos foram analisados por morfometria digital. A análise estatística foi realizada com o teste $t$ de Student. O nível de significância foi 0,05. Resultados: comparando as artérias ilíacas submetidas à angioplastia do grupo M200 com as do grupo SF, não houve diferença significativa da hiperplasia miointimal Conclusão: não houve diferença da hiperplasia miointimal nos grupos tratados com soro fisiológico e Moringa oleifera após angioplastia.
\end{abstract}

Descritores: Hiperplasia. Artéria llíaca. Moringa oleifera. Angioplastia. Coelhos.

\section{REFERENCES}

1. Dinis da Gama A. New trends in the prevention of myointimal hyperplasia and anastomotic fibroplasia. Rev Port Cir Cardiotorac Vasc. 2007;14(4):211-5.

2. Liu MW, Roubin GS, King SB 3rd. Restenosis after coronary angioplasty. Potential biologic determinants and role of intimal hyperplasia. Circulation. 1989;79(6):1374-87.

3. Ramachandran C, Peter KV, Gopalakrishnan PK. Drumstick (Moringa oleifera): a multipurpose Indian vegetable. Econ Bot. 1980;34(3):276-83.

4. Anwar F, Latif S, Ashraf M, Gilani AH. Moringa oleifera: a food plant with multiple medicinal uses. Phytother Res. 2007;21(1):1725 .

5. Kumar PS, Mishra D, Ghosh G, Panda CS. Medicinal uses and pharmacological properties of Moringa oleifera. Int J Phytomed. 2010:2(3):210-6

6. Bennett RN, Mellon FA, Foidl N, Pratt JH, Dupont MS, Perkins L, et al. Profiling glucosinolates and phenolics in vegetative and reproductive tissues of the multi-purpose trees Moringa oleifera L. (horseradish tree) and Moringa stenopetala L. J Agric Food Chem. 2003:51(12):3546-53.

7. Aslam M, Anwar F, Nadeem R, Rashid U, Kazi TG, Nadeem M Mineral Composition of Moringa oleifera Leaves and Pods from different regions of Punjab, Pakistan. Asian J Plant Sci. 2005;4(4):417-21.

8. Manguro LO, Lemmen P. Phenolics of Moringa oleifera leaves Nat Prod Res. 2007;21(1):56-68

9. Amaglo NK, Bennett RN, Lo Curto RB, Rosa EAS, Lo Turco V, Giuffrida A, et al. Profiling selected phytochemicals and nutrients in different tissues of the multipurpose tree Moringa oleifera L., grown in Ghana. Food Chem. 2010;122(4):1047-54.

10. Gowrishankar R, Kumar M, Menon V, Divi SM, Saravanan M, Magudapathy $P$, et al. Trace element studies on Tinospora cordifolia (Menispermaceae), Ocimum sanctum (Lamiaceae), Moringa oleifera (Moringaceae), and Phyllanthus niruri (Euphorbiaceae) using PIXE. Biol Trace Elem Res. 2010;133(3):35763 .

11. Scheller B, Speck U, Abramjuk C, Bernhardt U, Böhm M, Nickenig G. Paclitaxel balloon coating, a novel method for prevention and therapy of restenosis. Circulation. 2004;110(7):810-4.

12. Unverdorben $M$, Vallbracht $C$, Cremers $B$, Heuer $H$, Hengstenberg C, Maikowski $C$, et al. Paclitaxel-coated balloon catheter versus paclitaxel-coated stent for the treatment of coronary in-stent restenosis. Circulation. 2009;119(23):2986-94.

13. Scheller B, Hehrlein C, Bocksch W, Rutsch W, Haghi D, Dietz U, et al. Treatment of coronary in-stent restenosis with a paclitaxelcoated balloon catheter. N Engl J Med. 2006;355(20):2113-24.
14. Scheller B, Hehrlein C, Bocksch W, Rutsch W, Haghi D, Dietz U, et al. Two year follow-up after treatment of coronary in-stent restenosis with a paclitaxel-coated balloon catheter. Clin Res Cardiol. 2008;97(10):773-81.

15. Santos JAB. Estudo da aterosclerose induzida por diferentes tipos de dieta hiperlipídica em coelhos albinos (Oryctolagus cuniculus) [dissertação]. Macéio: Universidade Federal de Alagoas; 2008.

16. Vieira S. Metodologia Científica Para a Área de Saúde. São Paulo Sarvier; 1984.

17. Harkness JE, Wagner JE. Procedimentos clínicos. In: Harkness JE, editor. Biologia e Clínica de Coelhos e Roedores. 3a ed. São Paulo: Roca; 1993. p.57-85.

18. Fonseca NM, Goldenberg S, Gomes PO, dePaulaLima CA. Anestesia em coelhos. Acta Cir Bras. 1996;11(2):85-104.

19. INMETRO. Unidades Legais de Medida. Rio de Janeiro: Resolução n० 12 de 1988 do Conselho Nacional de Metrologia, Normalização e Qualidade Industrial - Conmetro; 1988 [updated 2007]; 8a. (revisada):[O Sistema Internacional de Unidades - SI]. Disponível em: http://www.inmetro.gov.br/consumidor/unidLegaisMed.asp.

20. Yanni AE. The laboratory rabbit: an animal model of atherosclerosis research. Lab Anim. 2004;38(3):246-56.

21. Brasselet C, Durand E, Addad F, Vitry F, Chatellier G, Demerens C, et al. Effect of local heating on restenosis and in-stent neointimal hyperplasia in the atherosclerotic rabbit model: a dose-ranging study. Eur Heart J. 2008;29(3):402-12.

22. Taylor JM, Fan J. Transgenic rabbit models for the study of atherosclerosis. Front Biosci. 1997;2:d298-308.

23. Kudo T, Chandra FA, Ahn SS. Long-term outcomes and predictors of iliac angioplasty with selective stenting. J Vasc Surg. 2005;42(3):466-75

24. Indolfi C, Torella D, Coppola C, Stabile E, Esposito G, Curcio A, et al. Rat carotid artery dilation by PTCA balloon catheter induces neointima formation in presence of IEL rupture. Am J Physiol Heart Circ Physiol. 2002;283(2):H760-7.

25. Mongiardo A, Curcio A, Spaccarotella C, Parise S, Indolfi C. Molecular mechanisms of restenosis after percutaneous peripheral angioplasty and approach to endovascular therapy. Curr Drug Targets Cardiovasc Haematol Disord. 2004;4(3): 275-87.

26. Mehta K, Balaraman R, Amin AH, Bafna PA, Gulati OD. Effect of fruits of Moringa oleifera on the lipid profile of normal and hypercholesterolaemic rabbits. J Ethnopharmacol. 2003;86(23):191-5.

27. Karas SP, Gravanis MB, Santoian EC, Robinson KA, Anderberg $K A$, King SB 3rd. Coronary intimal proliferation after balloon injury and stenting in swine: an animal model of restenosis. J Am Coll Cardiol. 1992;20(2):467-74

28. Le Tourneau T, Van Belle E, Corseaux D, Vallet B, Lebuffe G, Dupuis $B$, et al. Role of nitric oxide in restenosis after experimental 
balloon angioplasty in the hypercholesterolemic rabbit: effects on neointimal hyperplasia and vascular remodeling. J Am Coll Cardiol. 1999;33(3):876-82.

29. Jain PG, Patil SD, Haswani NG, Girase MV, Surana SJ. Hypolipidemic activity of Moringa oleifera Lam., Moringacae, on high fat diet induced hyperlipidemia in albino rats. Rev bras farmacogn. 2010;20(6):969-73.
Received in: 10/09/2015

Accepted for publication: 02/12/2015

Conflict of interest: none.

Source of funding: none.

Mailing address:

Janio Cipriano Rolim

E-mail: janio_rolim@hotmail.com 